\title{
Multilevel Analysis on the Contextual Effects of Hygiene, Environmental Sanitation, and Diarrhea Prevention in Elementary School Students in Ngawi, East Java
}

\author{
Dian Surya Kartika'), Setyo Sri Rahardjo²), Bhisma Murti1) \\ ${ }^{1)}$ Masters Program in Public Health, Universitas Sebelas Maret \\ ${ }^{2)}$ Faculty of Medicine, Universitas Sebelas Maret
}

\begin{abstract}
Background: Clean and healthy behavior in school is an important factor to prevent diarrhea and improve health status of school children. This study aimed to determine the effects of hygiene and school environmental sanitation on diarrhea prevention behavior.

Subjects and Method: This was an analytic observational study with a cross sectional design. This study was conducted in Ngawi, East Java, in October 2018. A sample of 225 elementary school students was selected randomly from 25 elementary high schools in Ngawi. The dependent variable was diarrhea prevention. The independent variables were student's knowledge, attitude, hygiene, school sanitation, school health unit, canteen sanitation, and maternal education. The data were collected by questionnaire and analyzed by a multilevel logistic regression run on Stata 13 .

Results: Good hygiene facility ( $\mathrm{b}=1.77 ; 95 \% \mathrm{CI}=0.66$ to $2.87 ; \mathrm{p}=0.002)$, good school sanitation $(b=1.37 ; 95 \% \mathrm{CI}=0.27$ to $2.48 ; \mathrm{p}=0.015)$, clean canteen $(\mathrm{b}=1.84 ; 95 \% \mathrm{CI}=0.23$ to $3.44 ; \mathrm{p}=0.025)$, school health unit $(b=1.49 ; 95 \% \mathrm{CI}=0.31$ to $2.68 ; \mathrm{p}=0.013)$, high student's knowledge $(b=2.30$; 95\% $\mathrm{CI}=1.20$ to $3.40 ; \mathrm{p}<0.001)$, positive attitude $(\mathrm{b}=2.03 ; 95 \% \mathrm{CI}=0.96$ to $3.10 ; \mathrm{p}<0.001)$, maternal education $\geq$ senior high school $(b=1.60 ; 95 \% \mathrm{CI}=0.37$ to $2.83 ; \mathrm{p}=0.011)$ were positively associated with diarrhea prevention. School had contextual effect on diarrhea prevention with $\mathrm{ICC}=54.03 \%$.

Conclusion: Good hygiene facility, good school sanitation, clean canteen, school health unit, high student's knowledge, positive attitude, maternal education $\geq$ senior high school are positively associated with diarrhea prevention in elementary school students. School has contextual effect on diarrhea prevention.
\end{abstract}

Keywords: diarrhea prevention, hygiene, school sanitation, elementary school student

\section{Correspondence:}

Dian Surya Kartika. Masters Program in Public Health, Universitas Sebelas Maret. Jl. Ir. Sutami No. 36 A, Surakarta, Central Java 57126, Indonesia. Email: kartikadiansurya@gmail.com.

Mobile: +6282230003592

\section{BACKGROUND}

The behavior of clean and healthy living in the school environment is one of the important factors to improve the health status of school children. School-age children are a group of people who are expected to grow into potential human resources in the future so that they need to be considered and prepared to be able to grow perfectly both physically and intellectually. Active cognitive education begins during primary education or in the age range of 612 years when the child is in an elementary school education institution (Ministry of Education and Culture of the Republic of Indonesia, 2017). The healthy behavior of children in elementary schools in Indonesia needs attention, especially the prevalence of worm infections in elementary school children in several regions in Indonesia is quite high and this is related to the behavior of elementary school children who tend to be 
Journal of Epidemiology and Public Health (2019), 4(2): 97-108

https://doi.org/10.26911/jepublichealth.2019.04.02.05

unhealthy such as not washing hands before/after eating, after going to the toilets and snacks at random (Darlan et al., 2017).

The sanitation and good hygiene practices are very important for the survival and development of children, while poor sanitation will have a negative impact on many aspects of life, one of them is an increase in the incidence of diarrhea. Diarrhea is influenced by hygiene, sanitation and behavior (Mbakaya et al., 2017; Mbuya and Humphrey, 2016). Hygiene and sanitation itself are known to be important for health, development, and education of children in general and are important for prevention of diarrhea in particular (Karon et al., 2017).

In the world, there are around 2.4 billion people who do not use good sanitation, and 663 million people do not have access to good water sources. In Indonesia, adequate clean water source facilities at the elementary school level are $64.76 \%$ with the availability of proper and separate latrines between male and female students $31.40 \%$. In East Java, the number of suitable and separate latrines between new male and female students reached $12.19 \%$, thus making East Java the lowest percentage of Javanese islands in terms of proper and separate latrine ownership between male and female students (Ministry of Education and Indonesian Culture, 2017). "Fit for School" program that integrates hygiene and sanitation intervention programs to prevent the occurrence of dental caries in primary school children has been reported successfully in Indonesia (Duijster et al., 2017).

Similar strategies, integrating hygiene, school environmental sanitation, and diarrhea prevention behaviors for prevention of diarrhea in elementary school children may be possible. For this reason, it is necessary to conduct study to determine hygiene, school environmental sanitation, and preventive behaviors of elementary school diarrhea for later use as an adequate development strategy, considering that in addition to the different hygiene and sanitation conditions in each region and environment, intervention strategies for children may be also different from intervention strategies for adults (Park et al., 2016; Watson et al., 2017).

Hygiene interventions for prevention of diarrhea should be carried out simultaneously with sanitation and healthy behavioral interventions for prevention of diarrhea (Mbakaya et al., 2017; Mbuya and Humphrey, 2016). The availability of good school sanitation will have an impact on health, simple activities such as hand washing with soap can reduce the risk of diarrheal disease by up to $47 \%$ (Freeman et al., 2014). Primary school children are vulnerable to be exposed to environmental pollutants, often carrying out unhealthy behaviors that cause diarrhea (Perlroth and Castelo, 2017; Ding et al., 2017).

Diarrhea in children is still a major health problem in the world, including in Indonesia (Komarulzaman et al., 2017; Mokomane et al., 2018). Diarrhea can interfere with the development, growth, and education of children, especially if it occurs repeatedly (Das and Bhutta, 2016; Karon et al., 2017; Mbuya and Humphrey, 2016). In addition to diarrhea, subclinical infections of pathogens, diarrhea can cause intestinal damage, chronic inflammation, and disruption of intestinal mucosal regeneration, which can lead to malnutrition and susceptibility to intestinal infections later in life (Prendergast AJ and Kelly, 2016; Syed et al., 2016). Every day, an estimated 4.7 million episodes of diarrheal disease, including around 100,000 severe diarrhea, with around 1,600 deaths in children (Keusch et al., 2016). Diarrhea 
cases in East Java amounted to $1,048,885$ cases, with cases handled 338,806 or $32.3 \%$. The incidence of diarrhea in East Java is second in Indonesia after West Java (East Java Provincial Health Office, 2016).

Ngawi Regency is one of the districts in East Java with the widest area has a geographical condition from the highlands or mountains, dry canyons to areas surrounded by river flow making access to sanitation in Ngawi has its own characteristics in each region. Primary schools in Ngawi were chosen because in addition to the ease of access to research, there was also a high rate of morbidity and mortality from diarrhea in elementary school children in Ngawi. Cases of diarrhea treated in Ngawi in 2016 amounted to 12,087 cases, with the largest age group experiencing deaths from diarrhea was elementary school age, amounting to 59.7\% (East Java Provincial Health Office, 2016).

In this study, researchers wanted to know the contextual influence between hygiene, school environmental sanitation and diarrhea prevention behavior in elementary school students in Ngawi district, East Java.

\section{SUBJECTS AND METHOD \\ 1. Study design \\ This was an analytic observational study with a cross sectional design. The study was conducted in Ngawi District, East Java, Indonesia, in October 2018.}

\section{Population and samples}

The source population in this study was elementary school students in Ngawi District. A sample of 225 students from 25 schools was selected by random sampling.

\section{Study variables}

The dependent variable is diarrhea prevention behavior. The independent variables at level 1 are maternal education, knowledge of students and students.
Hygiene facilities, school environment sanitation conditions, school health center, school canteen, and school strata at level 2.

\section{Operational definition of variables}

School sanitation was defined as the condition of infrastructure and facilities in schools which consisting of clean water, toilets, waste water disposal (SPAL), and waste disposal.

The school canteen or food sanitation was carried out so that safe food for food consumption and sanitation is carried out in activities or processes in the production, storage, transportation, and / or circulation of food.

School Health Center can be used as a place for health promotion about hygiene for school students.

Maternal education was the last formal education raised by mother. Mother was the person closest to the child who has a big influence on children's knowledge about diarrhea prevention behavior.

Student knowledge was defined as knowledge that influences practice either directly or indirectly. Knowledge of diarrhea prevention was related to proper hand washing, time to wash hands, snacking habits.

Attitude was defined as someone's feeling to support or not to support diarrhea prevention behavior.

Diarrhea prevention behavior include washing hands using running water and soap, washing hands before and after having meals, washing hands after going to the toilet, washing hands after playing, defecating in the toilet, urinating in the toilet, disposing of garbage in its place, eating in healthy school canteen.

\section{Study Instruments}

Hygiene facilities, school environment sanitation, health center unit, canteen, maternal education, student knowledge, attitude, and diarrhea prevention were 
Journal of Epidemiology and Public Health (2019), 4(2): 97-108

https://doi.org/10.26911/jepublichealth.2019.04.02.05

measured by questionnaire.

\section{Data Analysis}

Univariate analysis was performed to see the frequency distribution and the percentage of the characteristics of the research subjects. Bivariate analysis was conducted to study the relationship between the incidence of diarrhea and the independent variable using the chi-square test and calculation of odds ratios (OR) with a confidence level (CI) of 95\%. Furthermore multivariate analysis was performed using multiple logistic regression through a multilevel approach.

\section{Research Ethics}

The research ethics include informed consent, anonymity, confidentiality and ethical clearance. The ethical clearance in this study was obtained from Research Ethics Committee, Faculty of Medicine, Universitas Sebelas Maret, Surakarta, Central Java.

RESULTS

\section{Sample characteristics}

Table 1 described sample characteristics. Table 1 showed that out of 225 subjects, 108 people (48\%) are male and the female ones were 117 people (52\%). Meanwhile the number of students in grades 4, 5, and 6 is respectively 75 people (33\%). Poor hygiene facilities in schools were 126 (56\%). Poor school sanitation conditions were 133 (59.11\%). School Health Center (UKS) in good schools are 152 (67.56\%). The number of cafeteria in good schools is 142 (63.11\%). High-knowledge students were 123 people (54.67\%). Students with positive attitudes were 142 people (63.11\%). Mother's education $\geq$ senior high school is 137 people (60.89\%). Students with bad diarrhea prevention behavior were 128 (56.89\%).
Table 1. Sample characteristics

\begin{tabular}{|c|c|c|}
\hline Characteristics & $\mathbf{N}$ & $\%$ \\
\hline \multicolumn{3}{|l|}{ Gender } \\
\hline Male & 108 & 48 \\
\hline Female & 117 & 52 \\
\hline \multicolumn{3}{|l|}{ Grade } \\
\hline 4 & 75 & 33 \\
\hline 5 & 75 & 33 \\
\hline 6 & 75 & 33 \\
\hline \multicolumn{3}{|c|}{ Hygiene Facilities } \\
\hline Good & 99 & 44 \\
\hline Poor & 126 & 56 \\
\hline \multicolumn{3}{|c|}{ School Sanitation } \\
\hline Good & 92 & 40.89 \\
\hline Poor & 133 & 59.11 \\
\hline \multicolumn{3}{|l|}{ School Canteen } \\
\hline Good Canteen & 142 & 63.11 \\
\hline Poor Canteen & 83 & 36.89 \\
\hline \multicolumn{3}{|c|}{ School Health Unit } \\
\hline Good & 152 & 67.56 \\
\hline Poor & 73 & 32.44 \\
\hline \multicolumn{3}{|l|}{ Knowledge } \\
\hline High & 123 & 54.67 \\
\hline Low & 102 & $45 \cdot 33$ \\
\hline \multicolumn{3}{|l|}{ Attitude } \\
\hline Positive & 150 & 66.67 \\
\hline Negative & 75 & 33.33 \\
\hline \multicolumn{3}{|c|}{ Diarrhea Prevention } \\
\hline Good & 97 & 43.11 \\
\hline Poor & 128 & 56.89 \\
\hline \multicolumn{3}{|c|}{ Maternal Education } \\
\hline$<$ High School & 88 & 39.11 \\
\hline$\geq$ High School & 137 & 60.89 \\
\hline
\end{tabular}

\section{Bivariate Analysis}

Table 2 showed the results of bivariate analysis. Table 2 showed that good school facility hygiene $(\mathrm{OR}=4.73 ; 95 \% \mathrm{CI}=2.68$ to 8.35; $\mathrm{p}<0.001)$, good canteen sanitation $(\mathrm{OR}=2.83 ; 95 \% \mathrm{CI}=1.58$ to $5.08 ; \mathrm{p}$ $<0.001$ ), good school environment sanitation $(\mathrm{OR}=2.74 ; 95 \% \mathrm{CI}=1.58$ to 4.76 ; $\mathrm{p}<0.001)$, good school health unit $(\mathrm{OR}=$ $5.06 ; 95 \% \mathrm{CI}=2.60$ to $9.85 ; \mathrm{p}<0.001)$, good knowledge $(\mathrm{OR}=6.23 ; 95 \% \quad \mathrm{CI}=3.41$ to 11.39; $\mathrm{p}<0.001)$, good attitude $(\mathrm{OR}=2.64$; $95 \% \mathrm{CI}=1.45$ to $4.79 ; \mathrm{p}<0.001$ ), and good 
maternal education $(\mathrm{OR}=4.36 ; 95 \% \mathrm{CI}=$ 2.39 to $7.96 ; \mathrm{p}<0.001$ ) increased diarrhea prevention among elementary high school student.

Table 2. The results of bivariate analysis

\begin{tabular}{|c|c|c|c|c|c|c|c|}
\hline \multirow{3}{*}{ Variables } & \multicolumn{4}{|c|}{ Diarrhea prevention } & \multirow{3}{*}{$\mathbf{O R}$} & \multirow{3}{*}{$95 \% \mathrm{CI}$} & \multirow{3}{*}{$\mathbf{p}$} \\
\hline & \multicolumn{2}{|c|}{ Poor } & \multicolumn{2}{|c|}{ Good } & & & \\
\hline & $\mathbf{n}$ & $\%$ & $\mathbf{n}$ & $\%$ & & & \\
\hline \multicolumn{8}{|c|}{ Hygiene Facilities } \\
\hline Poor & 72 & 73 & 54 & 27 & 4.73 & 2.68 to 8.35 & $<0.001$ \\
\hline Good & 56 & 36.4 & 43 & 63.6 & & & \\
\hline \multicolumn{8}{|c|}{ School Canteen } \\
\hline Poor & 47 & 72.3 & 36 & 27.7 & 2.83 & 1.58 to 5.08 & $<0.001$ \\
\hline Good & 81 & 47.9 & 61 & 52.1 & & & \\
\hline \multicolumn{8}{|c|}{ School Sanition } \\
\hline Poor & 76 & 66.9 & 57 & 33.1 & 2.74 & 1.58 to 4.76 & $<0.001$ \\
\hline Good & 52 & 42.4 & 40 & 57.6 & & & \\
\hline \multicolumn{8}{|c|}{ School health unit } \\
\hline Poor & 42 & 80.8 & 31 & 19.2 & 5.06 & 2.60 to 9.85 & $<0.001$ \\
\hline Good & 86 & 45.4 & 66 & 54.6 & & & \\
\hline \multicolumn{8}{|l|}{ Knowledge } \\
\hline Low & 58 & 79.4 & 44 & 20.6 & 6.23 & 3.41 to 11.39 & $<0.001$ \\
\hline High & 70 & 38.2 & 53 & 61.8 & & & \\
\hline \multicolumn{8}{|l|}{ Attitude } \\
\hline Negative & 43 & 72 & 32 & 28 & 2.64 & 1.45 to 4.79 & $<0.001$ \\
\hline Positive & 85 & $49 \cdot 3$ & 65 & 50.7 & & & \\
\hline \multicolumn{8}{|c|}{ Maternal Education } \\
\hline$<$ High school & 50 & $77 \cdot 3$ & 38 & 22.7 & 4.36 & 2.39 to 7.96 & $<0.001$ \\
\hline$\geq$ High school & 78 & 43.8 & 59 & 56.2 & & & \\
\hline
\end{tabular}

\section{Multilevel analysis}

Table 3 shows that there was a positive relationship between hygiene facilities on diarrhea prevention behavior. Primary school students who attend school with good hygiene facilities had a greater possibility of good diarrhea prevention behavior than elementary school students who attend school with poor hygiene facilities $(b=1.77 ; 95 \% \mathrm{CI}=0.664$ to $2.87 ; \mathrm{p}$ $=0.002$ ).

There was a positive relationship between school sanitation on diarrhea prevention behavior. Primary school students who attend school with good school sanitation were more likely to have good diarrhea prevention behavior than primary school students who attend school with poor school sanitation $(\mathrm{b}=1.37$; $95 \% \mathrm{CI}=$ 0.27 to $2.48 ; \mathrm{p}=0.015$ ).
There was a positive relationship between canteen sanitation on diarrhea prevention behavior. Primary school students who attend school with good environmental sanitation conditions are more likely to have good diarrhea prevention behavior than primary school students who attend school with poor canteen sanitation $(b=1.84 ; 95 \% \mathrm{CI}=0.23$ to $3.44 ; \mathrm{p}=0.025)$.

There was a positive relationship between the condition of school health center on diarrhea prevention behavior. Primary school students who attend school with good environmental sanitation conditions are more likely to have good diarrhea prevention behavior than elementary school students who attend school with poor school health center conditions ( $\mathrm{b}=$ $1.49 ; 95 \% \mathrm{CI}=0.31$ to $2.68 ; \mathrm{p}=0.013$ ).

There was a positive relationship 
between students' knowledge about the prevention of diarrhea in diarrhea prevention behavior. Primary school students with high knowledge of prevention of diarrhea are more likely to have good diarrhea prevention behavior than primary school students with poor knowledge of diarrhea prevention $(\mathrm{b}=2.30 ; 95 \% \mathrm{CI}=1.20$ to 3.40 ; $\mathrm{p}<0.001)$.

There was a positive relationship between students' attitudes about preventing diarrhea in diarrhea prevention behavior. Primary school students with positive diarrhea prevention attitudes are more likely to have good diarrhea prevention behavior than primary school students with negative diarrhea prevention attitudes $(\mathrm{b}=$ 2.03; 95\% CI $=0.96$ to 3.10 ; $\mathrm{p}<0.001$ ).

There was a positive relationship between maternal education on diarrhea prevention behavior. Students with maternal education $\geq$ high school were more likely had good diarrhea preventive behavior than student with maternal education <high school $(b=1.60 ; 95 \% \mathrm{CI}=0.37$ to 2.83 ; $\mathrm{p}=0.011$ ).

Table 3. The results of multilevel analysis of factors associated with diarrhea prevention among elementary school students

\begin{tabular}{|c|c|c|c|c|}
\hline \multirow{2}{*}{ Variables } & \multirow{2}{*}{$\mathbf{b}$} & \multicolumn{2}{|c|}{$95 \% \mathrm{CI}$} & \multirow[b]{2}{*}{$\mathbf{p}$} \\
\hline & & Lower Limit & Upper Limit & \\
\hline \multicolumn{5}{|l|}{ Fixed Effect } \\
\hline Good hygiene facility & 1.77 & 0.66 & 2.87 & 0.002 \\
\hline $\begin{array}{l}\text { Good school environmental } \\
\text { sanitation }\end{array}$ & 1.37 & 0.26 & 2.48 & 0.015 \\
\hline Good SMU & 1.49 & 0.31 & 2.68 & 0.013 \\
\hline Good canteen conditions & 1.84 & 0.23 & 3.44 & 0.025 \\
\hline High knowledge & 2.30 & 1.20 & 3.40 & $<0.001$ \\
\hline Positive attitude & 2.03 & 0.96 & 3.10 & $<0.001$ \\
\hline $\begin{array}{l}\text { Maternal education } \geq \text { High School } \\
\text { Random Effect }\end{array}$ & 1.60 & 0.37 & 2.83 & 0.011 \\
\hline Maternal Education Variations & & 0.46 & 15.24 & \\
\hline School Canteen Variations & & 3.98 & 24.68 & \\
\hline Constants Variations & & 7.01 & 30.26 & \\
\hline \multicolumn{5}{|l|}{ n Observation $=225$} \\
\hline \multicolumn{5}{|l|}{ Average of $\mathrm{n}$ in eachSchool $=9$} \\
\hline \multicolumn{5}{|c|}{ Likelihood $=-650.50$} \\
\hline \multicolumn{5}{|c|}{ LR test vs. logistic regression, $\mathrm{p}<0.001$} \\
\hline
\end{tabular}

Table 3 showed that there was a variation of maternal education effect on diarrhea prevention behavior by 2.65 (CI $95 \%=0.46$ to 15.24$)$. There was a variation of school canteen effect on diarrhea prevention behavior by 9.91 (CI $95 \%=3.98$ to 24.68). There was a constant variation in the prevention behavior of diarrhea between schools by 14.56 (CI $95 \%=7.01$ to 30.26). School had a contextual effect on diarrhea prevention with $\mathrm{ICC}=54.03 \%$.

\section{DISCUSSION \\ 1. The effect of hygiene facility on diarrhea prevention behavior}

There was an effect of hygiene facility on diarrhea prevention behavior. The better the hygiene facilities in school, the better the preventive behavior of diarrhea. The result of this study was in line with a study 
by Karon et al., (2017), Jordanova et al., (2015), and Weaver et al., (2016) which stated that there was an effect of hygiene facility on diarrhea prevention behavior. The better and more affordable the hygiene facilities, the better the behavior and habits of children to wash their hands. According to Briceno et al., (2017), hygiene interventions in the form of handwashing with soap can be conducted together with sanitation interventions so that it can improve diarrhea prevention behavior.

\section{The effect of school sanitation on diarrhea prevention behavior}

There was an effect of school environmental sanitation on diarrhea prevention behavior. The better the school environmental sanitation, the better the preventive behavior of diarrhea. The result of this study was in line with a study by Mbakaya et al., (2017) and Humphrey (2016) which stated that good sanitation was closely related to good hygiene practices, while poor sanitation would have negative impacts, one of them was the increase in the incidence of diarrhea. Garn et al., (2016) and Jordanova et al., (2015) stated thatSchool sanitation conditions affected diarrhea prevention behavior, this study also showed that there was an effect of environmental sanitation on the incidence of diarrhea in children. Children with good environmental sanitation have a lower risk of experiencing diarrhea. Based on a study conducted by Freeman et al., (2014), good sanitation conditions have also been proven to increase students' hand washing activities and can reduce the risk of diarrheal disease by $47 \%$.

\section{The effect of school canteen on diarrhea prevention behavior}

There was an effect of school canteen on diarrhea prevention behavior. The better the school canteen, the better the preventive behavior of diarrhea. The result of this study was in line with a study done by Hasan and Richradson (2017) which stated that consuming unhygienic drinking water increased the risk of diarrhea in children. Because children/elementary school students spent most of their time in school. To get the food, school must provide a good and healthy school canteen so that it can improve diarrhea prevention behavior. According to the study of Ejemot-Nwadiaro et al., (2015) and Khatoon et al., (2017) the food and beverages must be covered so that they were not infested by animals/insects, did not eat/drink food/ beverage that were infested by animals/ insects (especially flies, cockroaches, etc.), eat/drink food and drinks that have been cooked well, and wash fruits/vegetables before eating, were important to prevent diarrhea.

\section{The effect of school health unit on diarrhea prevention behavior}

There was an effect of SMU on diarrhea prevention behavior. The better the condition and facility provided by SMU in schools, the better the preventive behavior of diarrhea.SMU as a school health program played an important role in providing health education, health services and fostering a healthy school environment. The result of this study was similar to a study done by Duijster et al. (2017) regarding the FIT for School and School Health Education Program on Personal Hygiene which explained that health education related to hygiene behavior in schools was important, after learning, students could conduct these activities in real life, and became a habit of healthy living behavior. According to Ejemot-Nwadiaro et al., (2015), promotion of handwashing and health education in schools could prevent diarrhea by by $25-30 \%$. According to Ding et al., (2017) and Karon et al., (2017), the involvement of schools was important for health promotion and health education, 
Journal of Epidemiology and Public Health (2019), 4(2): 97-108

https://doi.org/10.26911/jepublichealth.2019.04.02.05

students who learned about hygiene from their teachers were less likely to do open defecation and more often to share knowledge about washing their hands with their environment.

\section{The effect of knowledge on diarrhea prevention behavior}

There was an effect of students' knowledge on diarrhea prevention behavior. The higher the knowledge about diarrhea prevention, the better the preventive behavior of diarrhea. The result of this study was in line with a study done by Khatoon et al., (2017) which stated thatif the students have poor knowledge of personal hygiene, it would affect poor diarrhea prevention behavior. Seimetz et al., (2017) stated that diarrhea prevention behavior must be starting from creating awareness of the benefits of hand washing through health education and promotion activities. According to Mbakaya et al., (2017), hand washing habits were influenced by contextual, psychological and technological factors. Good knowledge regarding the benefits of prevention of diarrhea would instill good perceptions which would lead to good diarrhea prevention behaviors.

\section{The effect of students' attitude on diarrhea prevention behavior}

There was an effect of student attitude on diarrhea prevention behavior. Students' positive attitude would increase diarrhea prevention behavior. The result of this study was in line with a study by Slekiene and Mosler (2017) which stated that the distrust of the bad effects of not washing hands would cause elementary school students to not to wash their hands adequately. According to Mbakaya et al., (2017), it was necessary to implement selfefficacy, in addition, students can be given an induction of perceived threat of an infection to affect the habit of washing hands by using soap.

\section{The effect of maternal education on diarrhea prevention behavior}

There was an effect of maternal education on diarrhea prevention behavior. The higher the maternal education, the better the preventive behavior of diarrhea. The result of this study was in line with a study done by Karon et al., (2017) which stated that besides the school, parents' involvement was needed in promotions related to health education for the students. Mothers who have high level of education tend to have a positive influence on students' knowledge of diarrhea prevention. This was supported by the results of a study done by Mumtaz et al., (2017) which showed that the lack of maternal knowledge about the dangers of diarrhea caused a lack of attitudes and practices in the prevention and proper treatment of diarrhea. Similar findings were also found in a study done by Desta et al., (2017) which stated that maternal knowledge about diarrhea was directly related to the level of education, employment, and information obtained, the higher the level of education, the better the education and information obtained, and the easier it would be for mothers to provide knowledge about diarrhea prevention to their children.

\section{The effect of school on diarrhea prevention behavior}

From the results of multilevel analysis, the score of ICC was $54.03 \%$. The indicator showed that at the School level provided a contextual contribution by $54.03 \%$ to diarrhea prevention behavior. The result of this study was in line with the research of Sibiya and Gumbo (2013) which stated that adequate facilities greatly affected diarrhea prevention behavior, although the students have high knowledge and positive attitudes, students tend not to show good diarrhea prevention behavior because of the lack/ unavailability of facilities needed. This 
study also showed that facilities that support the prevention of diarrhea tend to be neglected due to lack of attention from the school. Schools in urban areas were better maintained. Greene et al., (2012) stated that washing hands by using soap effectively reduced the pathogen exposure to diarrhea, but this should be supported by the efforts to improve new facilities in schools such as latrine, provision of soap with an impressive amount for the number of students in the school. Karon et al., (2017) stated that school infrastructure played an important role, a healthy school environment, the availability of adequate facilities, good school health unit programs would support and encourage the students to have good diarrhea prevention behavior compared to schools with poor school environments, inadequate facilities, and inadequate health programs that would prevent the students to have good behavior of diarrhea prevention.

\section{$\frac{\text { REFERENCES }}{\text { Briceño B, Coville A, Gertler P, Martinez S }}$ (2017). Are there synergies from combining hygiene and sanitation promotion campaigns: Evidence from a large-scale cluster-randomized trial in rural Tanzania. PloS one. 12(11). doi: 10.1371/journal.pone.0186228.}

Cairncross S, Bartram J, Cumming O, Brocklehurst C (2010). Water, sanitation and hygiene for the prevention of diarrhea. International journal of epidemiology, 39(1), i193-205.

Cairncross S, Bartram J, Cumming O, Brocklehurst C (2010). Hygiene, sanitation, and water: what needs to be done?. PLoS medicine. 7 (11), e100o365. doi: 10.1371/journal.pmed.1000365 .

Cronin AA, Gnilo ME, Odagiri M, Wijesekera S. (2017). Equity Implications for Sanitation from Recent Health and Nutrition Evidence. International Journal for Equity in Health, 16(1), 211. doi: 10.1186/s12939-017-0709-5.

Darlan DM, Tala ZZ, Amanta C, Warli SM, Arrasyid NK (2017). Correlation between Soil Transmitted Helminth Infection and Eosinophil Levels among Primary School Children in Medan. Open Access Macedonian Journal of Medical Sciences, 5(2), 142-146.

Das JK, Bhutta ZA (2016). Global Challenges in Acute Diarrhea. Current Opinion in Gastroenterology, 32(1), 18-23.

Departemen Kesehatan Republik Indonesia (2009). Seri Perilaku Hidup bersih dan Sehat di Rumah Tangga: Menggunakan Jamban Sehat. Jakarta: Departemen Kesehatan Republik Indonesia Pusat Promosi Kesehatan.

Desta BK, Assimamaw NT, Ashenafi TD (2017). Knowledge, practice, and associated factors of home-based management of diarrhea among caregivers of children attending underfive clinic in Fagita Lekoma District, Awi Zone, Amhara Regional State, Northwest Ethiopia. Nursing Research and Practice, 8o84548(8). doi: 10.1155/2017/8084548

Dinas Kesehatan Provinsi Jawa Timur (2016). Profil Kesehatan Provinsi Jawa Timur Tahun 2016.

Ding Z, Zhai Y, Wu C, Wu H, Lu Q, Lin J, He F (2017). Infectious diarrheal disease caused by contaminated well water in Chinese schools: a systematic review and meta-Analysis. Journal of Epidemiology, 27(6), 274-281.

Duijster D, Monse B, Dimaisip-Nabuab J, Djuharnoko P, Heinrich-Weltzien R, Hobdell M, Kromeyer-Hauschild K, Kunthearith Y, et al. (2017). Fit for 
Journal of Epidemiology and Public Health (2019), 4(2): 97-108

https://doi.org/10.26911/jepublichealth.2019.04.02.05

school-a school-based water, sanitation and hygiene programme to improve child health: results from a longitudinal study in Cambodia, Indonesia and Lao PDR. BMC Public Health, 17(1), 302. doi: 10.1186/s12889-017-4203-1.

Ejemot-Nwadiaro RI, Ehiri JE, Arikpo D, Meremikwu MM, Critchley JA (2015). Hand washing promotion for preventing diarrhea. Cochrane Database of Systematic Reviews, 9. doi: 10.1002/14651858. CDoo4265.pub3.

Freeman MC, Meredith E, Oliver S, Aurelie C, Julian J, Higgins PT, Wolf J, PrüssUstün A, Bounjour S, Hunter PR, Fewtrell L, Curtis V (2014). Systematic Review: Hygiene and health: systematic review of handwashing practices worldwide and update of health effects. Tropical Medicine and International Health, 19(8), 906-916. doi.org/10.1111/tmi.12339

Garn JV, Brumback BA, Drews-Botsch CD, Lash TL, Kramer MR, Freeman MC (2016). Estimating the effect of school water, sanitation and hygiene improvements on Pupil health outcomes. Wolters Kluwer Health, 27(5): 7526o.doi: 10.1097/ede.0000000000000522

Greene LE, Freeman MC, Akoko D, Saboori S, Moe C, Rheingans R (2012). Impact of a school-based hygiene promotion and sanitation intervention on pupil hand contamination in Western Kenya: a cluster randomized trial. Am J Trop Med Hyg, 87(3), 385-93. doi: 10.4269/ajtmh.2012.11-0633.

Hasan MM, Richardson A (2017). How sustainable household environment and knowledge of healthy practices relate to childhood morbidity in South Asia: analysis of survey data from Bangladesh, Nepal and Pakistan. BMJ open, 7(6), e015019. doi:10.1136/bmjopen-2016-015019.

Jordanova T, Cronk R, Obando W, Medina OZ, Kinoshita R, Bartram J (2015). Water, sanitation, and hygiene in schools in low socio-economic regions in Nicaragua: A cross-sectional survey. Int. J. Environ. Res. Public Health, 12, 6197-6217; doi: 10. 3390/ ijerph120606197

Kamara JK, Galukande M Maeda F, Luboga S, Renzaho AMN (2017). Understanding the challenges of improving sanitation and hygiene outcomes in a community based intervention: a cross-sectional study in rural Tanzania. International Journal of Environmental Research and Public Health, 14(6), E602. doi: 10.3390/ijerph14060602.

Karon AJ, Cronin AA, Cronk R, Hendrawan $R$ (2017). Improving water, sanitation, and hygiene in schools in Indonesia: A cross-sectional assessment on sustaining infrastructural and behavioral interventions. International Journal of Hygiene and Environmental Health. 220(3): 539-550. doi: 10.1016/j.ijheh.2017.02.001.

Kementerian Pendidikan dan Kebudayaan (2017). Peta jalan sanitasi sekolah dalam kerangka UKS. Kementerian Pendidikan dan Kebudayaan.

Kementerian Pendidikan dan Kebudayaan Republik Indonesia (2017). Statistik sekolah dasar (SD) 2016/2017. Jakarta: Sekretariat Jenderal Pusat Data Dan Statistik Pendidikan Dan Kebudayaan.

Keusch GT, Walker CF, Das JK, Horton S, Habte D (2016). Diarrheal diseases. In: Black RE, Laxminarayan R, Temmerman M, Walker N, editors. Source Reproductive, Maternal, Newborn, and Child Health: Disease Con- 
trol Priorities. Washington (DC): The International Bank for Reconstruction and Development/ The World Bank, 3(2). doi: 10.1596/978-1-4648-03482_ch9

Khatoon R, Sachan B, Khan MA, Srivastava JP (2017). Impact of school health education program on personal hygiene among school children of Lucknow district. J Family Med Prim Care. 6(1), 97-100. doi: 10.4103/2249-4863.214973 .

Komarulzaman A, Smits J, de Jong E (2017). Clean water, sanitation and diarrhea in Indonesia: Effects of Household and Community Factors. Global Public Health, 12(9), 1141-1155. doi: 10.1080/17441692.2015.1127985.

La Con G, Schilling K, Harris J, Person B, Owuor M, Ogange L, Faith S, Quick R (2017). Evaluation of student handwashing practices during a schoolbased hygiene program in rural Western Kenya. International Quarterly of Community Health Education, 37(2), 121-128. doi: 10.1111/cobi.12263.

Mbakaya BC, Lee PH, Lee RL (2017). Hand hygiene intervention strategies to reduce diarrhoea and respiratory infections among school children in developing countries: A systematic review. International Journal of Environmental Research and Public Health, 14(4), E371. doi: 10.3390/ijerph14040371.

Mbuya MN, Humphrey JH (2016). Preventing Environmental Enteric Dysfunction Through Improved Water, Sanitation and Hygiene: An Opportunity for Stunting Reduction in Developing Countries. Maternal \& Child Nutrition, 12(1), 106-120. doi: 10.1111/mcn.12220.

Mokomane M, Kasvosve I, de Melo E,
Pernica JM, Goldfarb DM (2018). The Global Problem of Childhood Diarrheal Diseases: Emerging Strategies in Prevention and Management. Therapeutic Advances in Infectious Disease, 5(1), 29-43. doi: 10.1177/2049936117744429.

Mumtaz Y, Zafar M, Mumtaz Z (2014). Knowledge attitude and practices of mothers about diarrhea in children under 5 years. J Dow Uni Health Sci, 8(1), 3-6. doi: 10.15226/2576-4802/2/1/o0111.

Park MJ, Clements AC, Gray DJ, Sadler R, Laksono B, Stewart DE (2016). Quantifying accessibility and use of improved sanitation: Towards a comprehensive indicator of the need for sanitation interventions. Scientific Reports, 6, 30299. doi: 10.1038/srep30299.

Perlroth NH, Castelo Branco CW (2017). Current knowledge of environmental exposure in children during the sensitive developmental periods. Jornal de Pediatria (Rio J). 93(1), 17-27. doi: 10.1016/j.jped.2016.07.002.

Prendergast AJ, Kelly P (2016). Interactions between Intestinal Pathogens, Enteropathy and Malnutrition in Developing Countries. Current Opinion in Infectious Diseases, 29(3), 229-236. doi: 10.1016/j.ebiom.2016.07.030 .

Seguin M, Niño ZM (2015). Non-clinical interventions for acute respiratory infections and diarrhoeal diseases among young children in developing countries. Tropical Medicine \& International Health. 20(2), 146-169. doi: 10.1111/tmi.12423.

Seimetz E, Slekiene J, Friedrich M, Mosler HJ (2017). Identifying behavioural determinants for interventions to increase handwashing practices 
among primary school children in rural Burundi and urban Zimbabwe. BMC research notes, 10(1), 280. doi:10.1186/s13104-017-2599-4

Shrestha RM, Miyaguchi M, Shibanuma A, Khanal A, Yasuoka J, Jimba M (2016). A School Health Project Can Uplift the Health Status of School Children in Nepal. PloS one, 11(11), e0166001. doi:10.1371/journal.pone.0166001

Sibiya JE, Gumbo JR (2013). Knowledge, attitude and practices (KAP) survey on water, sanitation and hygiene in selected schools in Vhembe District, Limpopo, South Africa. International journal of environmental research and public health, 10(6), 2282-2295. doi:10.3390/ijerph10062282

Slekiene J, Mosler HJ (2017). Does Depression Moderate Handwashing in Children?. BMC Public Health, 18(1), 82. doi: 10.1186/s12889-017-4638-4.

Weaver ER, Agius PA, Veale H, Dorning K, Hlang TT, Aung PP, Fowkes FJ, Hellard ME (2016). Water, Sanitation, and Hygiene Facilities and Hygiene Practices Associated with Diarrhea and Vomiting in Monastic Schools, Myanmar. American Journal of Tropical Medicine and Hygiene, 95(2), 278-287. doi: 10.4269/ajtmh.15-O290 . 